\title{
TRADE AND GROWTH IN A NON-RECOGNIZED SMALL ISLAND STATE: EVIDENCE FROM THE TURKISH REPUBLIC OF NORTHERN CYPRUS
}

\author{
Salih Katircioglu \\ Department of Banking and Finance, \\ Eastern Mediterranean University, \\ P.O. Box 95, Famagusta, North Cyprus, Via Mersin 10, Turkey \\ E-mail:salihk@emu.edu.tr
}

Received 5 March 2009; accepted 20 February 2010

\begin{abstract}
This paper empirically investigates long-run equilibrium relationship and causality between international trade and economic growth in North Cyprus, which has a non-recognized state and suffers from the Cyprus problem for more than 40 years. Results reveal that long-run equilibrium relationship exists between international trade variables (exports and imports of goods and services) and economic growth in this small island state. The present study also validates the existence of export-led growth hypothesis in Northern Cyprus while it rejects the validity of import-led growth hypothesis. Finally, this study has shown that Turkish Cypriots should improve not only services exports but also merchandise exports in to contribute to its economy further.
\end{abstract}

Keywords: International Trade, Economic Growth, Bounds Test, Causality, North Cyprus.

Reference to this paper should be made as follows: Katırcioglu, S. 2010. Trade and growth in a non-recognized small 1sland state: evidence from the Turkish Republic of Northern Cyprus, Journal of Business Economics and Management 11(1): 112-130.

\section{Introduction}

International tourism and international trade are two major sources of foreign exchange for small countries as well as the larger ones. Small countries, in particular small islands, have more dependency on trade than the larger ones since their economies are based on only a few sectors. For example, according to Kuznets (1966), as the country gets smaller, its dependency on international trade would increase. On the other hand, although many economists agree that small countries have similar advantages and disadvantages when compared to the larger ones, there are differences in the origin of these disadvantages. Among common disadvantages are international trade dependency, vulnerability, high population growth rate, limited labor force, low labor efficiency, diseconomies of scale, low GDP (Gross Domestic Product), high dependency on imports of intermediate and consumption goods, and production of only a few basic goods/services.

The small size of a country, in terms of area and population, may be economically advantageous. The smallness of a state in terms of area and population may in fact be a 
source of comparative advantage rather than being a constraint on economic growth and development. Specifically, smallness may be more than compensated by certain unique characteristics possessed by small states. Export-oriented services tend to represent such uniqueness and, therefore, a basis for a potential comparative advantage (Mehmet and Tahiroglu 2002).

Many studies in the literature proved the importance of international trade for economic growth well. Some support the ELG hypothesis while others support the ILG hypothesis for particular countries. Although results on the direction of relationship between international trade and economic growth are again inconclusive (Balaguer and CantavellaJorda 2002), these studies prove that international trade is crucial for economic growth of many countries (Shun and Sun 1998; Xu 1996; Jin and Shih 1995; Bahmani-Oskooee and Alse 1993; Marin 1992; Chow 1987). Grybaitė and Tvaronavičienè (2008) conduct a work to investigate the role of organizations for sustainable development. They find that organizations for sustainable development review progress at the international, regional and national levels in the implementation of sustainable development policy for the purpose of taking part in legislative process, controlling balance between economic development, social development, and environmental development. On the other hand, Tvaronavičius and Tvaronavičienè (2008) again prove the importance of fixed investments in economic growth in the case of Lithuania.

This study empirically investigates the possible link between international trade (mainly exports and imports) and economic growth in a small island, Turkish Republic of Northern Cyprus (TRNC), which is not a recognized state (only recognized by its mainland, Turkey). This study is important in the sense that it, as a first time, considers the relationship between international trade and real income growth in this small island state which suffers from foreign trade relationships with the other countries due to the political reasons. The present study also employs the latest econometric techniques of the bounds test to level relationships, conditional error correction models and conditional Granger causality tests in order to investigate this relationship.

The TRNC was established in 1983 in a divided Cyprus and is not recognized by countries other than the mainland Turkey. North Cyprus has a population well over 265,000 with 10,537 US\$ per capita income (State Planning Organization (SPO) 2009) and is located in a strategic location of the earth. International tourism and the emergence of higher education sector are two major sources of foreign exchange to this small island since TRNC does not have considerable foreign trade relationship with countries other than Turkey due to the political non-recognition; tourism sector also faces great difficulties in attracting international tourists because of the problems such as the lack of direct flights to North Cyprus and high transportation costs.

Having the above mentioned features of North Cyprus, this study will give important messages to policy makers.

\section{Foreign Trade in North Cyprus}

Like many other typical small economies, the TRNC has based its development on a few sector: Tourism, higher education, banking and foreign trade. The official cur- 
rency unit is the Turkish Lira (TL) of mainland Turkey. Therefore, the country does not possess its own monetary policy. The foreign trade balance of the country has given persistent deficits over the years. Tourism, higher education and the banking sector have been outstanding sectors after the 1990s. The history of Cyprus, its somewhat unusual political circumstances and the small size of the domestic market played a crucial role in shaping the national economy. Suffering from international non-recognition, a very limited economic relationship with the other countries, limited natural resources and a small population, North Cyprus has a considerably small and a service dependent economy. $72 \%$ of GNP (Gross National Product) was contributed by the service sector, while industry and agriculture generated almost $28 \%$ of GNP (State Planning Organization (SPO) 2009). North Cyprus has a relatively less diversified economic structure. Its economy vitally depends on foreign trade, final goods for consumption and raw materials that are mainly imported from abroad for domestic production.

"The political problems have also slowed the rate of economic growth in North Cyprus, intensifying the impact of physical and economic constraints such as water shortage and persistent trade deficits" (Wilson 1992). Although it is a non-recognized state, North Cyprus has its own regional boundaries, laws and an autonomous political and economic policy that governs trade and the limited international relations with other countries. Major problems faced in foreign trade other than political and economic isolation arise basically because of high costs in transportation, inadequate foreign marketing and re-export problem. However, on the other side, organizations (economic agents) in the countries should be well functioning (Grybaite and Tvaronavičienè 2008), and investments should be efficient and productive for the economies (Tvaronavičius and Tvaronavičiene 2008). These issues in the TRNC are the areas that should be taken seriously in account to make them contribute to economic well being no matter how political problems create burden for the economy.

North Cyprus adopts a liberal trade policy and conducts trade relations (mainly imports) with more than 60 countries over the world. The major trade partner of the country is mainland Turkey and the United Kingdom (U.K.). The U.K. was the first major trading partner until 1994 when a decision of European Court of Justice (ECJ) imposed restrictions on imports of the U.K. and the other European countries from North Cyprus. Therefore, the situation changed after that year. There were huge declines in exports to the U.K. and to the other European countries. In 2008, 46.0\% of total exports of the TRNC went to Turkey and goods imported from Turkey totaled for $60.1 \%$ (State Planning Organization (SPO) 2009).

Cyprus traditionally has an agrarian economy. Currently in the agricultural sector of North Cyprus productivity is low and underemployment is high. Its development is seriously handicapped by the lack of water resources and low investment in the sector. Agricultural and industrial products including processed agricultural goods are worth examining in the overall exports of North Cyprus. But, there is a rapid fall in the export of agricultural products in parallel to a fall in the agricultural production, because of long years of drought on the island. The share of agricultural products accounted for $77.5 \%$ of total exports in 1977 while it dropped to $34.0 \%$ in 2008 . The share of indus- 
trial products accounted for $12.1 \%$ of total exports in 1977 while it increased to $63.6 \%$ in 2008 (State Planning Organization (SPO) 2009). Among the main agricultural and industrial products exported from North Cyprus are live lambs \& kids, dairy products, citrus crops, concentrated citrus, fresh vegetables, potatoes, carobs, olive and olive oil, non-alcoholic refreshments, tobacco and cigarettes, hides and leather, wool and readymade clothes. Total exports of North Cyprus were 62.0 million US \$ while imports were 853.1 million US \$ in 2008. Among the important export partners of North Cyprus other than Turkey and the U.K. are Israel, Kuwait, Saudi Arabia, Russia, Lebanon, and U.S.A.. On the other hand, the other major import sources for North Cyprus are Hong Kong, Taiwan, Singapore, Sri Lanka, and the European Union (E.U.) countries (State Planning Organization (SPO) 2009).

The decision of the ECJ in 1994 to restrict the exports of the TRNC to the U.K. market in the first stage, and to the other countries in the second stage, seriously damaged the country's export potential. The Court ruled that health certificates issued by North Cyprus authorities were not to be accepted as substitutes for the legally recognized Cyprus government's documents. This meant that citrus fruit and potatoes' exports to the U.K. market would no longer receive preferential trade treatment and overall exports could no longer carry the TRNC stamp. Afterwards, the British authorities interpreted this decision to cover all exports and began to impose trade restrictions by eliminating preferential trade status of export commodities from North Cyprus. Furthermore, textile exports, which entered European Union markets under EURO 1 documents, could no longer receive preferential treatment, because the Court's decision underlined the fact that the TRNC was not a recognised state. Additionally, textile exports to the E.U. market from North Cyprus would be subject to an additional tax of $14 \%$. As a result, the exports of North Cyprus received a major blow by the ECJ decision. Since the ECJ decision to restrict exports to the U.K. and E.U. markets, North Cyprus has been using "Turkey's (Mersin)" stamp for its exported goods. Unfortunately, this decision has brought a great burden to the TRNC's foreign trade and economy in general ${ }^{1}$.

The paper proceeds as follows. Section 2 overviews the literature on the relationship between international trade and growth. Section 3 defines theoretical setting of the empirical methodology. Section 4 defines data and methodology of the study. Section 5 provides results and discussions and the paper concludes with Section 6.

\section{International trade and growth}

This section attempts to provide a review of the literature with an emphasis on international trade and economic growth. Exports of goods and services postulate the existence of various arguments for which exports become a main determinant of overall long-run economic growth. More specifically, export revenues bring in foreign exchange which can be used to import capital goods in order to produce goods and services, leading

\footnotetext{
${ }^{1}$ For detailed information see Yeşilada and Biçak (1995), The European Court Of Justice Decision On Trade With Northern Cyprus: Implications For The Cyprus Conflict, Presented to the Conference of the 91th Annual Meeting and Exhibition of the American Political Science Association, Chicago, USA.
} 
in turn to economic growth (Balaguer and Cantavella-Jorda 2002; Xu 1998). Thus, international trade can be thought of one within the other that together contributes to economic growth. Exports plus imports divided by GDP is a well known measure for openness of a country (See Yanikkaya 2003). Since small economies have more trade dependency, the openness rate of these countries is also higher than larger ones. Recent theoretical literature provides two main mechanisms through which international openness may affect growth. The first is its effect on the rate of innovation. The second is its effect on the adoption rate of technologies from more advanced countries that also increases the economy's rate of total factor productivity growth (Proudman et al. 1998). Whether export promotion leads to economic growth has been subject to considerable debate in the development and growth literature. Newly industrialized Asian countries in particular, Hong Kong, Singapore, Korea, Taiwan, Malaysia and Thailand - can be cited as examples of countries experiencing the ELG. This strategy of growth has doubled their standards of living in every ten year cycle. Many studies have tested the ELG hypothesis for economic growth to search for the relationship between export growth and economic growth. Extensive empirical studies in the literature have adopted the concept of causality proposed by Granger (1969) and Sims (1972) to detect the causal relationship between exports and output. Many of the studies in the empirical literature show conflicting results. Furthermore, although exports are a component of GDP and thus lead directly to the growth of output, while some studies found support for the export-led growth hypothesis (i.e. Chow 1987; Bahmani-Oskooee and Alse 1993; Xu 1996), some others have found negative relationship, even for the economies that are well known for their export promoting policies (i.e. Jung and Marshall 1985; Darrat 1996; Ahmad and Kwan 1991; Dodaro 1993).

The new trade theory has contributed to the theoretical relationship between exports and growth regarding effects on technical efficiency (Doyle 2001). Rivera-Batiz and Romer (1991) show that expansion of international trade increases growth by increasing the number of specialized production inputs. However, this outcome is ambiguous when there is imperfect competition and increasing returns to scale (Doyle 2001). Krugman (1979), Dixit and Norman (1980) and Lancaster (1980) show economies of scale as a major cause of international trade, hinting the validity of the growth-led exports hypothesis. There are extensive empirical studies of the Trade-Led Growth (TLG) hypothesis which fail to produce conclusive findings (Giles and Williams 1999; Deme 2002). Some empirical studies in the literature confirmed the TLG hypothesis for some countries whereas some others rejected it for some other countries, while, on the other hand, some studies in the growth literature support the ELG hypothesis and while some others investigate the ILG hypothesis (Deme 2002).

In the last decade, in addition to cross-country applications, time series and causality analyses examining the export and economic growth relationship has gained importance. Additionally, the concept of the ILG hypothesis was also practically considered in addition to the ELG hypothesis having the fact that imports are mainly vital for raw materials, as well as intermediate goods and capital goods which are used in the production process of exported goods and services. This mechanism stimulates economic growth 
for many countries. In the work of Bahmani-Oskooee and Alse (1993), bidirectional causality between export growth and economic growth was empirically tested.

Katircioglu (2009) investigated the relationship between international trade and real income growth in the case of the south of Cyprus and found that exports and imports of Cyprus are real income driven in the long-term. Furthermore, a change in international trade (exports and imports) precedes a change in international tourism in the case of (the south) Cyprus according to the findings of Katircioglu (2009).

Koccat (2008) finds no long-run equilibrium relationship between real income per capita, real exchange rates and real exports of goods and services in the case of Turkey based on the Johansen methodology. Omotor (2008) does not support the export-led economic growth hypothesis in the Nigerian economy. Chang et al. (2000) added imports to the relationship between exports and GDP and founded a bidirectional relationship between income and exports, income and imports, and exports and imports in the case of Taiwan. Arize (2002) found a long run convergence and therefore a long run equilibrium relationship between exports and imports using data for 50 countries around the world. This was parallel to the findings of Stilianos and Jyh-Lin (1999), Granger (1986), Gould and Ruffin (1996) and Husted (1992). Howard (2002) worked on the causality between exports, imports and income (GDP) in Trinidad and Tobago, a petroleum exporting country where oil export booms raise income levels but are usually followed by a slump. He found a unidirectional Granger causation from exports to income and bidirectional causation between exports and imports, and imports and income. He also hinted to the importance of the relationship between export growth and income due to a promotion of export sector as a key to economic growth and development in most of the developing countries.

Chow (1987) found a bi-directional causality export growth and economic growth for Hong Kong, Israel, Singapore, Taiwan and Brazil, unidirectional causality from export to economic growth for Mexico and no causality between these two for Argentina using the Sims procedure. Jung and Marshall (1985) used Granger causality tests and supported the ELG hypothesis for four out of thirty seven developing countries under consideration. They also found significant output growth and export growth relationship for three countries, an export-reducing growth relationship for six countries and a growth-reducing exports relationship for three countries. The empirical literature on ELG world wide generally shows that export growth plays an important role in economic growth, although many countries have recently adopted liberalization in their trade policies. Empirical studies also proved that developing countries with favorable export growth have experienced high economic growth rates. Therefore, this shows that exports are one of the major sources of foreign currency for national economies.

\section{Theoretical setting}

There are huge amount of studies studying the determinants of economics growth especially within the growth accounting framework. Many studies have modeled export-led and import-led growth equations where both exports and imports were assumed to be important determinants of economic growth as also discussed in the previous section of the present study. Furthermore, exchange rates are considered as a very important 
variable affecting international trade and its relationship with economic growth. Thus, the following functional relationship can be established with this regard:

$$
y_{t}=f\left(T_{t}, \mathrm{RER}_{t}\right)
$$

where real income $(y)$ is a function of international trade $(T)$ and real exchange rates (RER).

This functional relationship in equation (1) can then be expressed in logarithmic form to capture the growth impact:

$$
\ln y_{t}=\beta_{0}+\beta_{1} \ln T_{t}+\beta_{2} \ln \mathrm{RER}_{t}+\varepsilon_{t},
$$

where at period $t$, lny is the natural $\log$ of real income; $\ln T$ is the natural $\log$ of international trade variable; lnRER is the natural $\log$ of real exchange rates; and $\varepsilon$ is the error disturbance. The expected sign of coefficent for $\mathrm{T}$ is positive in equation (2) implying that growth in international trade and real exchange rates are likely to exert positive impact on real income growth.

There is an assumption that real income in equation (2) may not immediately adjust to their long-run equilibrium level following a change in any of their determinants (See also Narayan, P. K. and Narayan, S. 2005); therefore, the speed of adjustment between the short-run and the long-run levels of real income can be captured by estimating the following error correction model:

$$
\Delta \ln y_{t}=\beta_{0}+\sum_{i=1}^{n} \beta_{1} \Delta \ln y_{t-j}+\sum_{i=0}^{n} \beta_{2} \Delta \ln T_{t-j}+\sum_{i=0}^{n} \beta_{3} \Delta \ln \operatorname{RER}_{t-j}+\beta_{4} \varepsilon_{t-1}+u_{t},
$$

where $\Delta$ represents change in $y, T$, and RER variables and $\varepsilon_{\mathrm{t}-1}$ is the one period lagged error correction term (ECT), which is estimated from equation (2). The ECT in equation (3) shows how fast the disequilibrium between the short-run and the long-run values of dependent variable is eliminated each period. The expected sign of ECT is negative (See Gujarati 2003).

\section{Data and methodology}

Data used in this paper are annual figures covering the period 1977-2008 and variables of the study are real gross domestic product (GDP), real exports of goods and services, real imports of goods and services, and real exchange rates in the TRNC. Data are taken from State Planning Organization of the TRNC (SPO) (2009) and variables are all at 2000 constant USD prices. The present study will use exports and imports as international trade variables rather than using trade volume.

The Phillips-Perron (PP) ${ }^{2}$ Unit Root Test was employed to test the integration level and the possible co-integration among the variables (Dickey and Fuller 1981; Phillips and Perron 1988). The PP procedures, which compute a residual variance that is robust to auto-correlation, are applied to test for unit roots as an alternative to ADF unit root test. To investigate long-run relationship between each pair of variables under considera-

\footnotetext{
${ }^{2}$ PP approach allows for the presence of unknown forms of autocorrelation with a structural break in the time series and conditional heteroscedasticity in the error term.
} 
tion, the bounds test for co-integration within ARDL (the autoregressive distributed lag) modeling approach was adopted in this study. This model was developed by Pesaran et al. (2001) and can be applied irrespective of the order of integration of the variables (irrespective of whether regressors are purely I (0), purely I (1) or mutually co-integrated). The ARDL modeling approach involves estimating the following error correction models:

$$
\begin{aligned}
& \Delta \ln Y_{t}=a_{0_{Y}}+\sum_{i=1}^{n} b_{i_{Y}} \Delta \ln Y_{t-i}+\sum_{i=0}^{n} c_{i_{Y}} \Delta \ln X_{t-i}+\sum_{i=0}^{n} d_{i_{Y}} \Delta \ln Z_{t-i}+\sigma_{1_{Y}} \ln Y_{t-1}+ \\
& \sigma_{2_{Y}} \ln X_{t-i}+\sigma_{3_{Y}} \ln Z_{t-1}+\varepsilon_{1 t} ; \\
& \Delta \ln X_{t}=a_{0_{X}}+\sum_{i=1}^{n} b_{i_{X}} \Delta \ln X_{t-i}+\sum_{i=0}^{n} c_{i_{X}} \Delta \ln Y_{t-i}+\sum_{i=0}^{n} d_{i_{X}} \Delta \ln Z_{t-i}+\varpi_{1_{X}} \ln X_{t-1}+ \\
& \varpi_{2_{X}} \ln Y_{t-i}+\varpi_{3_{X}} \ln Z_{t-i}+\varepsilon_{2 t} .
\end{aligned}
$$

In equations (4) and (5), $\Delta$ is the difference operator, $\ln Y_{t}$ is the natural log of the dependent variable, $\ln X_{t}$ and $\ln Z_{t}$ are the natural $\operatorname{logs}$ of the independent variables and $\varepsilon_{1 \mathrm{t}}$ and $\varepsilon_{2 \mathrm{t}}$ are serially independent random errors with mean zero and finite covariance matrix.

Again, in equations (4) and (5), the F-test is used for investigating a (single) long-term relationship in a trivariate system. In the case of a long-term relationship, the F-test indicates which variable should be normalized. In equation (4), when $\ln Y$ is the dependent variable, the null hypothesis of no cointegration is $\mathrm{H}_{0}: \sigma_{1 Y}=\sigma_{2 Y} \sigma_{3 Y}=0$ and the alternative hypothesis of cointegration is $\mathrm{H}_{1}: \sigma_{1 Y} \neq \sigma_{2 Y} \neq \sigma_{3 Y} \neq 0$. On the other hand, in equation (5), when $\ln \mathrm{X}$ is the dependent variable, the null hypothesis of no cointegration is $\mathrm{H}_{0}: \varpi_{1 X}=\varpi_{2 X}=\varpi_{3 X}=0$ and the alternative hypothesis of cointegration is $\mathrm{H}_{1}$ : $\varpi_{1 X} \neq \varpi_{2 X} \neq \varpi_{3 X} \neq 0$.

In the case of level relationships, the conditional ECMs using the ARDL approach will be employed in this study in order to estimate equation (2). As also suggested by Pesaran et al. (2001), the time series properties of the key variables (tourism, education, and GDP in this case) in the conditional ECMs of the present study can be approximated by double-log EC (p) (error correction at $\mathrm{p}$ lag levels that might be different for each explanatory variable) models under the ARDL approach, augmented with appropriate deterministics such as intercepts and time trends. Then, the conditional ECM of interest using the ARDL approach can be written as:

$$
\begin{aligned}
& \Delta \ln Y_{t}=\Delta \beta_{0}+\sum_{j=1}^{p-1} \phi_{j} \Delta \ln Y_{t-i}+\sum_{i=1}^{k} \beta_{i_{0}} \Delta \ln X_{i t}+ \\
& \sum_{i=1}^{k} \sum_{j=1}^{q-1} \beta_{i j} \Delta X_{i, t-j}+\varphi \Delta Z_{t}+\gamma(1, p) \mathrm{ECT}_{t-1}+u_{t},
\end{aligned}
$$

where $\phi_{j}, \beta_{i j}$, and $\varphi$ are the coefficients for the short-run dynamics of the model's convergence to equilibrium. The coefficient of $\gamma(1, p)$ denotes the speed of adjustment and is expected to be negative.

In the case of level relationships based on the bounds test, conditional Granger causality tests should be carried out under the vector error correction model (VECM). By do- 
ing so, the short-run deviations of series from their long-run equilibrium path are also captured by including an error correction term (See also Narayan and Smyth 2004). Therefore, conditional vector error correction models for Granger causality under the trivariate system can be specified as follows:

$$
\begin{aligned}
& \Delta \ln Y_{t}=\alpha_{0}+\varphi_{11}^{p}(L) \Delta \ln Y_{t}+\varphi_{12}^{q}(L) \Delta \ln X_{t}+ \\
& \varphi_{13}^{r}(L) \Delta \ln Z_{t}+\delta \mathrm{ECT}_{t-1}+u_{1 t}, \\
& \Delta \ln X_{t}=\alpha_{0}+\varphi_{21}^{p}(L) \Delta \ln X_{t}+\varphi_{22}^{q}(L) \Delta \ln Y_{t}+ \\
& \varphi_{23}^{r}(L) \Delta \ln Z_{t}+\delta \mathrm{ECT}_{t-1}+u_{2 t},
\end{aligned}
$$

where

$$
\begin{aligned}
& \varphi_{11}^{p}(L)=\sum_{i=1}^{P_{11}} \varphi_{11, i}^{p} L^{i}, \quad \varphi_{12}^{p}(L)=\sum_{i=0}^{P_{12}} \varphi_{12, i}^{p} L^{i}, \\
& \varphi_{13}^{p}(L)=\sum_{i=0}^{P_{13}} \varphi_{13, i}^{p} L^{i}, \quad \varphi_{21}^{p}(L)=\sum_{i=1}^{P_{21}} \varphi_{21, i}^{p} L^{i}, \\
& \varphi_{22}^{p}(L)=\sum_{i=0}^{P_{22}} \varphi_{22, i}^{p} L^{i}, \quad \varphi_{23}^{p}(L)=\sum_{i=0}^{P_{23}} \varphi_{23, i}^{p} L^{i} .
\end{aligned}
$$

In equations (7) and (8), $\Delta$ denotes the difference operator and $\mathrm{L}$ denotes the lag operator where $(L) \Delta \ln Y_{t}=\Delta \ln Y_{t-1} . E C T_{t-1}$ is the lagged error correction term derived from the long-run model. Finally, $\mu_{1 t}$ and $\mu_{2 t}$ are serially independent random errors with mean zero and finite covariance matrix. Finally, according to the VECM for causality tests, having statistically significant $t$ ratios for $\mathrm{ECT}_{\mathrm{t}-1}$ in equations (7) and (8) would meet conditions to have long-run causations.

\section{Results and discussion}

Table 1 gives ADF and PP unit root test results for the variables under consideration. Both tests reveal that real GDP, exports, imports, and RER variables are non-stationary at their levels but become stationary at their first differences. Therefore, $y, X, M$, and RER are said to be integrated of order one, I (1) in the case of North Cyprus.

Bounds test will be now employed to investigate long-run equilibrium relationship between international trade variables and real GDP of North Cyprus within the ARDL modeling approach as suggested by Pesaran et al. (2001). Critical values for F statistics for small samples are presented in Table 2 as taken from Narayan (2005) to be used in this study. Table 3 gives the results of the bounds test for level relationships by trivariate systems (including real exchange rates) between real GDP and international trade variables in North Cyprus. These models are under three different scenarios as suggested by Pesaran et al. (2001), which are with restricted deterministic trends $\left(\mathrm{F}_{\mathrm{IV}}\right)$, with unrestricted deterministic trends $\left(\mathrm{F}_{\mathrm{V}}\right)$ and without deterministic trends $\left(\mathrm{F}_{\mathrm{III}}\right)$. Intercepts in these scenarios are all unrestricted ${ }^{3}$.

\footnotetext{
${ }^{3}$ For detailed information, please refer to Pesaran et al. (2001: 295-296).
} 
Table 1. ADF and PP tests for unit root

\begin{tabular}{lcccccccc}
\hline Statistics (Level) & $\ln y$ & $\operatorname{Lag}$ & $\operatorname{Ln} X$ & $\operatorname{Lag}$ & $\ln M$ & lag & $\ln R E R$ & lag \\
\hline$\tau_{\mathrm{T}}(\mathrm{ADF})$ & -1.89 & $(1)$ & -2.59 & $(0)$ & -2.79 & $(3)$ & -1.45 & $(0)$ \\
\hline$\tau_{\mu}(\mathrm{ADF})$ & 1.62 & $(0)$ & -1.89 & $(0)$ & -0.06 & $(0)$ & -1.56 & $(0)$ \\
\hline$\tau(\mathrm{ADF})$ & 2.11 & $(0)$ & -0.10 & $(0)$ & 1.39 & $(0)$ & -0.04 & $(0)$ \\
\hline$\tau_{\mathrm{T}}(\mathrm{PP})$ & -1.52 & $(1)$ & -2.68 & $(1)$ & -1.85 & $(1)$ & -1.29 & $(3)$ \\
\hline$\tau_{\mu}(\mathrm{PP})$ & 1.29 & $(2)$ & -1.91 & $(1)$ & -0.19 & $(1)$ & -1.68 & $(2)$ \\
\hline$\tau(\mathrm{PP})$ & 1.62 & $(3)$ & -0.09 & $(2)$ & 1.32 & $(1)$ & -0.04 & $(2)$ \\
\hline Statistics (First Difference) $)$ & $\Delta \ln y$ & $\mathrm{Lag}$ & $\Delta \ln X$ & $\operatorname{lag}$ & $\Delta \ln M$ & $\operatorname{lag}$ & $\Delta \ln R E R$ & $\operatorname{lag}$ \\
\hline$\tau_{\mathrm{T}}(\mathrm{ADF})$ & $-4.47^{*}$ & $(0)$ & $-5.67^{*}$ & $(0)$ & $-4.03^{* *}$ & $(3)$ & $-5.81^{*}$ & $(0)$ \\
\hline$\tau_{\mu}(\mathrm{ADF})$ & $-3.75^{*}$ & $(0)$ & $-5.77^{*}$ & $(0)$ & $-3.99^{*}$ & $(3)$ & $-4.93^{*}$ & $(0)$ \\
\hline$\tau(\mathrm{ADF})$ & $-3.40^{*}$ & $(0)$ & $-5.86^{*}$ & $(0)$ & $-4.47^{*}$ & $(0)$ & $-5.02^{*}$ & $(0)$ \\
\hline$\tau_{\mathrm{T}}(\mathrm{PP})$ & $-4.48^{*}$ & $(1)$ & $-5.68^{*}$ & $(1)$ & $-4.72^{*}$ & $(3)$ & $-6.00^{*}$ & $(4)$ \\
\hline$\tau_{\mu}(\mathrm{PP})$ & $-3.77^{*}$ & $(3)$ & $-5.78^{*}$ & $(1)$ & $-4.67^{*}$ & $(1)$ & $-4.93^{*}$ & $(2)$ \\
\hline$\tau(\mathrm{PP})$ & $-3.45^{*}$ & $(3)$ & $-5.86^{*}$ & $(0)$ & $-4.46^{*}$ & $(1)$ & $-5.02^{*}$ & $(2)$ \\
\hline
\end{tabular}

Note: y represents real gross domestic product; $X$ is real exports; $M$ is real imports; and RER is real exchange rates. All of the series are at their natural logarithms. $\tau_{\mathrm{T}}$ represents the most general model with a drift and trend; $\tau_{\mu}$ is the model with a drift and without trend; $\tau$ is the most restricted model without a drift and trend. Numbers in brackets are lag lengths used in ADF test (as determined by AIC set to maximum 3) to remove serial correlation in the residuals. When using PP test, numbers in brackets represent Newey-West Bandwith (as determined by Bartlett-Kernel). Both in ADF and PP tests, unit root tests were performed from the most general to the least specific model by eliminating trend and intercept across the models (See Enders, 1995: 254-255). ${ }^{*}$ denotes the rejection of the null hypothesis at $1 \%$ level. Tests for unit roots have been carried out in E-VIEWS 6.0.

Table 2. Critical values for ARDL modeling approach

\begin{tabular}{ccccccc}
\hline & \multicolumn{2}{c}{0.10} & \multicolumn{2}{c}{0.05} & \multicolumn{2}{c}{0.01} \\
\hline $\mathrm{k}=3$ & $\mathrm{I}(0)$ & $\mathrm{I}(1)$ & $\mathrm{I}(0)$ & $\mathrm{I}(1)$ & $\mathrm{I}(0)$ & $\mathrm{I}(1)$ \\
\hline $\mathrm{F}_{\mathrm{IV}}$ & 3.38 & 4.27 & 4.05 & 5.09 & 5.67 & 6.99 \\
\hline $\mathrm{F}_{\mathrm{V}}$ & 3.87 & 4.97 & 4.68 & 5.98 & 6.64 & 8.31 \\
\hline $\mathrm{F}_{\mathrm{III}}$ & 5.33 & 7.06 & 3.71 & 5.02 & 5.33 & 7.06 \\
\hline $\mathrm{t}_{\mathrm{V}}$ & -3.13 & -3.84 & -3.41 & -4.16 & -3.96 & -4.73 \\
\hline $\mathrm{t}_{\mathrm{III}}$ & -2.57 & -3.46 & -2.86 & -3.78 & -3.43 & -4.37 \\
\hline
\end{tabular}

Source: Narayan (2005) for F-statistics and Pesaran et al. (2001) for t-ratios.

Notes: (1) $\mathrm{k}$ is the number of regressors for dependent variable in ARDL models, $\mathrm{F}_{\text {IV }}$ represents the $\mathrm{F}$ statistic of the model with unrestricted intercept and restricted trend, $\mathrm{F}_{\mathrm{V}}$ represents the $\mathrm{F}$ statistic of the model with unrestricted intercept and trend, and $\mathrm{F}_{\mathrm{III}}$ represents the $\mathrm{F}$ statistic of the model with unrestricted intercept and no trend. (2) $\mathrm{t}_{\mathrm{V}}$ and $\mathrm{t}_{\mathrm{III}}$ are the $\mathrm{t}$ ratios for testing $\sigma_{1 Y}=0$ in Equation (4) and $\varpi_{1 Y}=0$ in Equation (5) respectively with and without deterministic linear trend. 
Table 3. The bounds test for co-integration

\begin{tabular}{|c|c|c|c|c|c|c|}
\hline \multirow[b]{2}{*}{ Variables } & \multicolumn{3}{|c|}{$\begin{array}{l}\text { With Deterministic } \\
\text { Trends }\end{array}$} & \multicolumn{2}{|c|}{$\begin{array}{c}\text { Without } \\
\text { Deterministic Trend }\end{array}$} & \multirow[b]{2}{*}{ Conclusion } \\
\hline & $\mathrm{F}_{\mathrm{IV}}$ & $\mathrm{F}_{\mathrm{V}}$ & $\mathrm{t}_{\mathrm{V}}$ & $\mathrm{F}_{\mathrm{III}}$ & $\mathrm{t}_{\mathrm{III}}$ & \\
\hline & & & & & & $\mathrm{H}_{0}$ \\
\hline \multicolumn{7}{|l|}{ (1) y and $X$} \\
\hline $\mathrm{F}_{\mathrm{y}}(\ln \mathrm{y} / \ln \mathrm{X}, \ln \mathrm{RER})$ & & & & & & Rejected \\
\hline $\mathrm{p}=1$ & $13.43 \mathrm{c}$ & $13.43 \mathrm{c}$ & $-5.14 c$ & - & - & \\
\hline 2 & $7.75 \mathrm{c}$ & $9.68 \mathrm{c}$ & $-4.69 \mathrm{c}$ & $0.37 \mathrm{a}$ & $0.95 \mathrm{a}$ & \\
\hline 3 & $5.54 \mathrm{c}$ & $7.35 \mathrm{c}$ & $-4.51 c$ & $0.02 \mathrm{a}$ & $0.13 \mathrm{a}$ & \\
\hline 4 & $2.30 \mathrm{a}$ & $3.38 \mathrm{a}$ & $-2.72 \mathrm{a}$ & $0.30 \mathrm{a}$ & $0.18 \mathrm{a}$ & \\
\hline 5 & - & - & - & $0.37 \mathrm{a}$ & $0.93 \mathrm{a}$ & \\
\hline $\mathrm{F}_{\mathrm{X}}(\ln \mathrm{X} / \ln \mathrm{y}, \ln \mathrm{RER})$ & & & & & & Rejected \\
\hline $\mathrm{p}=1$ & $7.17 \mathrm{c}$ & $7.24 \mathrm{c}$ & $-4.26 c$ & $4.37 \mathrm{a}$ & $-2.36 \mathrm{a}$ & \\
\hline 2 & $5.46 \mathrm{c}$ & $6.49 \mathrm{c}$ & $-3.74 b$ & $3.33 \mathrm{a}$ & $-2.19 \mathrm{a}$ & \\
\hline 3 & $3.56 b$ & $4.75 b$ & $-3.44 b$ & $1.18 \mathrm{a}$ & $-1.45 \mathrm{a}$ & \\
\hline 4 & $1.03 \mathrm{a}$ & $1.27 \mathrm{a}$ & $-0.84 \mathrm{a}$ & $1.40 \mathrm{a}$ & $-1.43 \mathrm{a}$ & \\
\hline
\end{tabular}

(2) y and $M$

$\mathrm{F}_{\mathrm{y}}(\ln \mathrm{y} / \ln \mathrm{M}, \ln R E R)$

Rejected

\begin{tabular}{ccccccc}
\hline $\mathrm{p}=1$ & $5.67 \mathrm{c}$ & $5.04 \mathrm{c}$ & $-2.59 \mathrm{a}$ & $5.52 \mathrm{~b}$ & $-1.80 \mathrm{a}$ & \\
\hline 2 & $3.47 \mathrm{~b}$ & $4.35 \mathrm{~b}$ & $-2.53 \mathrm{a}$ & $3.11 \mathrm{a}$ & $-2.12 \mathrm{a}$ & \\
\hline 3 & $2.55 \mathrm{a}$ & $3.17 \mathrm{a}$ & $-2.21 \mathrm{a}$ & $2.18 \mathrm{a}$ & $-1.69 \mathrm{a}$ & \\
\hline 4 & $3.34 \mathrm{a}$ & $4.23 \mathrm{~b}$ & $-1.31 \mathrm{a}$ & $3.53 \mathrm{a}$ & $-0.04 \mathrm{a}$ & \\
\hline $\mathrm{F}_{\mathrm{M}(\operatorname{lnM} / \ln , \operatorname{lnRER})}$ & & & & & & Rejected \\
\hline $\mathrm{p}=3$ & $3.18 \mathrm{a}$ & $3.37 \mathrm{a}$ & $-2.39 \mathrm{a}$ & $4.50 \mathrm{a}$ & $-2.71 \mathrm{a}$ & \\
\hline 4 & $4.65 \mathrm{c}$ & $5.75 \mathrm{c}$ & $-1.10 \mathrm{a}$ & $6.64 \mathrm{~b}$ & $-1.08 \mathrm{a}$ & \\
\hline 5 & $4.07 \mathrm{~b}$ & $4.82 \mathrm{~b}$ & $-1.60 \mathrm{a}$ & $5.88 \mathrm{~b}$ & $-1.63 \mathrm{a}$ & \\
\hline 6 & $3.64 \mathrm{~b}$ & $2.94 \mathrm{a}$ & $-1.33 \mathrm{a}$ & $6.42 \mathrm{~b}$ & $-1.53 \mathrm{a}$ & \\
\hline
\end{tabular}

Note: Akaike Information Criterion (AIC) and Schwartz Criteria (SC) were used to select the number of lags required in the co-integration test. $\mathrm{p}$ shows lag levels and $*$ denotes optimum lag selection in each model as suggested by both AIC and SC. F IV represents the F statistic of the model with unrestricted intercept and restricted trend, $\mathrm{F}_{\mathrm{V}}$ represents the $\mathrm{F}$ statistic of the model with unrestricted intercept and trend, and $\mathrm{F}_{\mathrm{III}}$ represents the $\mathrm{F}$ statistic of the model with unrestricted intercept and no trend. $t_{\mathrm{V}}$ and $t_{\mathrm{III}}$ are the $t$ ratios for testing $\sigma_{1 \mathrm{Y}}=0$ in Equation (4) and $\varpi_{1 \mathrm{Y}}=0$ in Equation (5) respectively with and without deterministic linear trend. ${ }^{a}$ indicates that the statistic lies below the lower bound, ${ }^{b}$ that it falls within the lower and upper bounds, and ${ }^{\mathrm{c}}$ that it lies above the upper bound. 
Results in Table 3 suggest that the application of the bounds F-test using ARDL modeling approach suggest level relationships in all of the four models presented in Table 4. This is because the null hypotheses of $\mathrm{H}_{0}: \sigma_{1 Y}=\sigma_{2 Y}=\sigma_{3 Y}=0$ and $\mathrm{H}_{0}: \varpi_{1 Y}=\varpi_{2 Y}=$ $\varpi_{3 Y}=0$ in equations (4) and (5) respectively can be rejected according to bounds test results in Table 3 . International trade variables (exports and imports) and real GDP are in long-run equilibrium relationship. The results from the application of the bounds ttest in the ARDL models do not generally allow for the imposition of the trend restrictions in the models since they are not statistically significant with very few exceptions (See Pesaran et al. 2001).

Having level relationships in bounds tests, the ARDL approach can be now adopted to estimate the level relations as also discussed in Pesaran and Shin (1999) and formulated in equation (2) of the present study. The resulted estimates of level relationships for the ARDL specification in the case of growth-export model and growth-import model can be given by:

Export-Growth Relationship in equation (2):

$y_{t}=0.830\left(X_{t}\right)-0.683\left(R E R_{t}\right)+11.172+\hat{u}_{t}$
$(0.081)$
$(0.045)$
$(0.725)$

Import-Growth Relationship in equation (2):

$\mathrm{y}_{\mathrm{t}}=0.529\left(M_{t}\right)-0.174\left(R E R_{t}\right)+5.108+\hat{u}_{t}$
$(0.113)$
$(0.163)$
(2.405)

where $\hat{u}_{t}$ is error correction term and standard errors are given in parantheses in both models. Both models as provided above show that exports (0.830) and imports $(0.529)$ have inelastic but positive and statistically significant coefficients for real income growth in Northern Cyprus.

In the next stage, the conditional ECM regressions associated with the above level relationships should be estimated. These are provided in Table 4.

Table 4. The ARDL Error Correction Models

Export-growth Model $(0,3,1)$

\begin{tabular}{lccc}
\hline Regressor & Coefficient & Standard Error & p-value \\
\hline$\hat{\mathrm{u}}_{\mathrm{t}-1}$ & -0.990 & 0.144 & 0.000 \\
\hline$\Delta \ln \mathrm{X}$ & 0.444 & 0.069 & 0.000 \\
\hline$\Delta \ln \mathrm{X}_{\mathrm{t}-1}$ & -0.252 & 0.093 & 0.013 \\
\hline$\Delta \ln \mathrm{X}_{\mathrm{t}-2}$ & -0.116 & 0.066 & 0.092 \\
\hline$\Delta \operatorname{lnRER}$ & -0.416 & 0.064 & 0.000 \\
\hline Intercept & 0.072 & 0.008 & 0.000 \\
\hline
\end{tabular}

Adj. $\mathrm{R}^{2}=0.912$, S.E. of Regr. $=0.043$,

$\mathrm{AIC}=-3.247, \mathrm{SBC}=-2.961$,

F-stat. $=57.109$, F-prob. $=0.000$,

D-W stat. $=2.132$

Note: * denotes p lag structures in each model. 
Import-growth Model (2, 5, 3)

\begin{tabular}{|c|c|c|c|}
\hline Regressor & Coefficient & Standard Error & $p$-value \\
\hline$\hat{u}_{t-1}$ & -0.635 & 0.106 & 0.000 \\
\hline$\Delta \ln y_{t-1}$ & 0.470 & 0.131 & 0.002 \\
\hline$\Delta \ln \mathrm{M}$ & 0.420 & 0.050 & 0.000 \\
\hline$\Delta \ln \mathrm{M}_{\mathrm{t}-1}$ & -0.261 & 0.066 & 0.001 \\
\hline$\Delta \ln \mathrm{M}_{\mathrm{t}-2}$ & 0.030 & 0.045 & 0.517 \\
\hline$\Delta \ln \mathrm{M}_{\mathrm{t}-3}$ & 0.100 & 0.036 & 0.014 \\
\hline$\Delta \ln \mathrm{M}_{\mathrm{t}-4}$ & -0.108 & 0.050 & 0.046 \\
\hline$\triangle \ln R E R$ & -0.144 & 0.072 & 0.065 \\
\hline$\Delta \operatorname{lnRER}{ }_{\mathrm{t}-1}$ & -0.023 & 0.079 & 0.770 \\
\hline$\Delta \operatorname{lnRER}{ }_{\mathrm{t}-2}$ & 0.216 & 0.063 & 0.003 \\
\hline Intercept & 0.026 & 0.009 & 0.012 \\
\hline
\end{tabular}

Adj. $\mathrm{R}^{2}=0.940$, S.E. of Regr. $=0.034$

$\mathrm{AIC}=-3.623, \mathrm{SBC}=-3.091$,

F-stat. $=40.851$, F-prob. $=0.000$,

D-W stat. $=2.541$

Note: * denotes p lag structures in each model.

Results in Table 4 show that ECTs are reasonably high, statistically significant and have expected signs in both models; equilibrium correction term for exports and growth relationship is -0.990 and it is -0.635 for imports and growth relationship. This shows that dependent variable (real income) in both export and import equations converge at high levels (99.0\% in export equation and $63.5 \%$ in import equation) to its long-term equilibrium level. On the other hand, the lagged coefficients in the short term are generally and statistically significant except two lagged term of import variable and one lagged term of RER variable in the second model. Short run coefficients in both models are all inelastic.

Finally, the direction of causality can be now searched within the conditional Granger causality tests that employ the ARDL mechanism as a long-run context. F-statistics for short-run causations and $t$ statistics of ECTs for long-run causations are given in Table 5 as they are estimated from equations (7) and (8).

Results from Table 5 suggest bidirectional causality between export growth and real income growth since $t$ statistics for ECTs are statistically significant. F-statistics did not reveal any short-term causation between export growth and real income growth since they are not statistically significant. On the other hand, results from Table 5 did not 
reveal any causation between import growth and real income growth neither in the long term nor the short term since both $\mathrm{t}$ and $\mathrm{F}$ statistics are not significant. To summarize, results in the present study confirms the validity of export-led growth hypothesis while they reject import-led growth hypothesis in the long-term of Northern Cyprus economy as can be seen from Figure 1 .

Table 5. Results of conditional Granger causality tests

For Exports and Growth

\begin{tabular}{|c|c|c|c|c|}
\hline \multicolumn{5}{|c|}{ F-statistics [probability values] } \\
\hline Dependent Variable & $\Delta \operatorname{lng}_{\mathrm{t}}$ & $\Delta \ln X_{t}$ & $\Delta \operatorname{lnRER} R_{\mathrm{t}}$ & t-stat (prob) for $\mathrm{ECT}_{\mathrm{t}-1}$ \\
\hline$\Delta \ln y_{t}$ & - & $\begin{array}{c}2.299 \\
{[0.141]}\end{array}$ & $\begin{array}{c}0.559 \\
{[0.729]}\end{array}$ & $\begin{array}{c}-3.263 \\
{[0.011]}\end{array}$ \\
\hline$\Delta \ln \mathrm{X}_{\mathrm{t}}$ & $\begin{array}{c}0.832 \\
{[0.561]}\end{array}$ & - & $\begin{array}{c}0.540 \\
{[0.741]}\end{array}$ & $\begin{array}{c}-2.537 \\
{[0.034]}\end{array}$ \\
\hline$\Delta \ln R_{E R} R_{t}$ & $\begin{array}{c}4.286 \\
{[0.034]}\end{array}$ & $\begin{array}{c}2.522 \\
{[0.117]}\end{array}$ & - & $\begin{array}{c}4.940 \\
{[0.001]}\end{array}$ \\
\hline
\end{tabular}

For Imports and Growth

\begin{tabular}{lcccc}
\hline \multicolumn{5}{c}{ F-statistics [probability values] } \\
\hline Dependent Variable & $\Delta \operatorname{lng}_{\mathrm{t}}$ & $\Delta \operatorname{lnM}_{\mathrm{t}}$ & $\Delta \operatorname{lnRER}_{\mathrm{t}}$ & t-stat $\left(\right.$ prob) for $\mathrm{ECT}_{\mathrm{t}-1}$ \\
\hline$\Delta \operatorname{lny}_{\mathrm{t}}$ & - & $2.176[0.157]$ & 0.315 & 0.938 \\
& & & {$[0.890]$} & {$[0.375]$} \\
\hline$\Delta \operatorname{lnM}_{\mathrm{t}}$ & 1.259 & - & 0.662 & 2.406 \\
& {$[0.366]$} & & {$[0.662]$} & {$[0.042]$} \\
\hline$\Delta \operatorname{lnRER}_{\mathrm{t}}$ & 0.963 & 1.474 & - & -1.372 \\
& {$[0.492]$} & {$[0.297]$} & & {$[0.207]$} \\
\hline
\end{tabular}

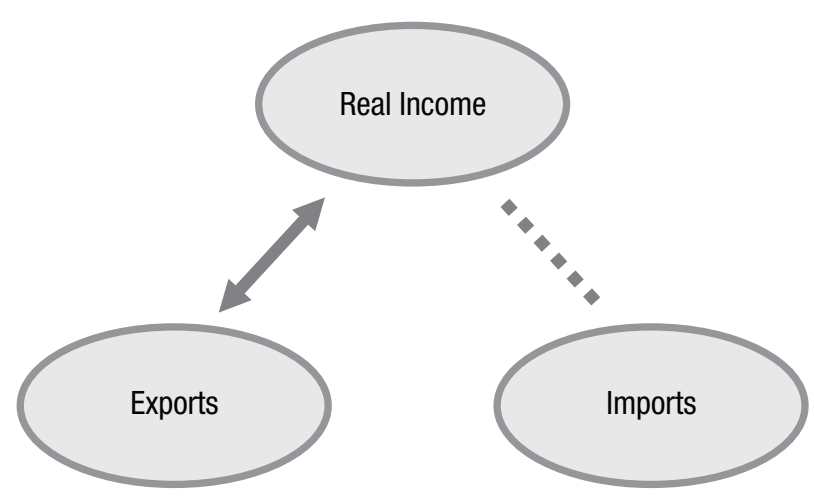

Fig. 1. International Trade and Economic Growth in North Cyprus 


\section{Conclusions}

This paper empirically investigated long-run equilibrium relationship and causality between international trade and economic growth in the TRNC, which has a non-recognized state, and political and economic relations only with its mainland, Turkey. Results of the present study reveal that long-run equilibrium relationship exists between international trade variables (exports and imports) and economic growth in this small island state. Both long-term and short-term effects of exports and imports on economic growth of the island are inelastic but statistically significant. Furthermore, this study suggest bidirectional causality between export growth and real income growth in the long term. This validates the existence of export-led growth hypothesis in Northern Cyprus. Thus, it can be said that export growth (in the goods and services) is catalyst for economic growth in the case of TRNC. On the other hand, conditional Granger causality tests did not identify any causality between import growth (in the goods and services) neither in the long term nor the short term; this rejects the validity of import-led growth hypothesis in this small island state.

The major sources of income in the TRNC are the aids provided by Turkey on annual basis and foreign exchange earnings generated from international tourism, exports, and higher education sector. Although merchandise exports have declined seriously over the years, higher education sector has led to a major inflow of foreign exchange into the island. Traditional tourism revenues are mainly contributed by casino tourism (as visitors come from Turkey on daily basis) and visits of Greek Cypriots from the south. Contribution of the visits by foreigners from the other countries to international tourism revenues are quite rare due to the problems faced in this sector and in the political arena; but it is mainly the services sector that make total exports contribute to the economy. Turkish Cypriot authorities should focus not only on improving services exports but also traditional merchandise exports. Owing to the political reasons in international arena, domestic production cannot be exported to the other countries. Even, merchandise exports made to the mainland Turkey are not sufficient; thus, there are many excess products, which are dead due to the fact that they cannot be sold to outside. Merchandise export is a serious issue that should be taken into attention by the state authorities.

The establishment of higher education instututions in North Cyprus has started to contribute to income and employment generation apart from 1990s. More than 40,000 international students come and study at the universities of the TRNC every year especially apart from 1990s; this brought many opportunities for job creation and enhanced better employment in the main sectors of the economy. Inspite of political non-recognition and Cyprus problem, it seems that higher education sector will continue to develop and contribute further to the TRNC economy in the coming years. On the other hand, the TRNC experienced great difficulties in attracting international tourists from the other countries to the island. After the borders between the north and the south of Cyprus were opened in 2003, many tourists visiting the south of Cyprus have been crossing to the north on daily basis. Casino sector is also an important factor in attracting international tourists from the south and even from Turkey since this sector is forbidden in the south of Cyprus and Turkey. In addition to a development planning in higher education 
sector, state authorities in TRNC should also develop policies in order to enable international tourists to make their choice of travel for North Cyprus. Experience from the previous years has shown that planning and policies towards improving tourism sector of TRNC were not so successful especially before 2003. Finally, being a recognized state, the south of Cyprus has succeeded to attract many tourists from different regions of the world. As of 2008, private universities have also been established in the south of Cyprus, which might be a major threaten for the universities in the north of Cyprus in the nearest future; this situation should be seriously considered by the Turkish Cypriot authorities.

A further and similar research can be also done for the south of Cyprus for comparison with the results of the present study.

\section{References}

Ahmad, J.; Kwan, A. C. C. 1991. Causality between exports and economic growth, Economics Letters 37(3): 243-248. doi:10.1016/0165-1765(91)90218-A

Arize, A. C. 2002. Imports and exports in 50 countries: Tests of co-integration and structural breaks, International Review of Economics \& Finance 11(1): 101-115.

doi:10.1016/S1059-0560(01)00101-0

Bahmani-Oskooee, M.; Alse, J. 1993. Export growth and economic growth: An application of co-integration and error correction modeling, The Journal of Developing Areas 27(4): 535-542.

Balaguer, J.; Cantavella-Jorda, M. 2002. Tourism as a long-run economic growth factor: The Spanish case, Applied Economics 34(7): 877-884. doi:10.1080/00036840110058923

Chang, T.; Fang, W.; Liu, W.; Henry, T. 2000. Exports, imports and income in Taiwan: An examination of the export led growth hypothesis, International Economic Journal 14(2): 151-160. doi:10.1080/10168730000080015

Chow, P. C. Y. 1987. Causality between export growth and industrial development: Empirical evidence from the NICs, Journal of Development Economics 36: 405-415.

Darrat, A. F. 1996. Trade and development: The Asian experience, Cato Journal 6(2): 695-699.

Deme, M. 2002. An examination of the trade-led growth hypothesis in Nigeria: A co-integration, causality, and impulse response analysis, The Journal of Developing Areas 36(1): 1-15.

Dickey, D.; Fuller, W. A. 1981. Likelihood ratio statistics for autoregressive time series with a unit root, Econometrica 49: 1057-1072. doi:10.2307/1912517

Dixit, A.; Norman, V. 1980. Theory of international trade. Cambridge: Cambridge University Press.

Dodaro, S. 1993. Exports and growth: A reconsideration of causality, The Journal of Developing Areas 27: 227-244.

Doyle, E. 2001. Export-output causality and the role of exports in Irish growth: 1950-1997, International Economic Journal 15(3): 31-54. doi:10.1080/10168730100080018

Giles, J. A.; Williams, C. L. 1999. Export-led growth: A survey of the empirical literature and some non-causality results. Econometrics Working Paper, EWP9901, Department of Economics, University of Victoria, Canada.

Gould, D. M.; Ruffin, R. J. 1996. Trade deficits: Causes and consequences, Federal Reserve Bank of Dallas Economic Review $4^{\text {th }}$ quarter: 10-20.

Granger, C. W. J. 1969. Investigating causal relations by econometric models and cross-spectral methods, Econometrica 36: 424-438. doi:10.2307/1912791 
Granger, C. W. J. 1986. Developments in the study of co-integrated variables, Oxford Bulletin of Economics and Statistics 48(3): 213-228.

Grybaite, V.; Tvaronavičienè, M. 2008. Estimation of sustainable development: germination on institutional level, Journal of Business Economics and Management 9(4): 327-334. doi:10.3846/1611-1699.2008.9.327-334

Gujarati, D. N. 2003. Basic econometrics. $4^{\text {th }}$ Edition. Mc Graw-Hill International.

Howard, M. 2002. Causality between exports, imports and income in Trinidad and Tobago, International Economic Journal 16(4): 97-106. doi:10.1080/10168730200000030

Husted, S. 1992. The emerging U. S. current account deficit in the 1980s: A co-integration analysis, Review of Economics and Statistics 74: 159-166. doi:10.2307/2109554

Jin, C. J.; Shih, Y. C. 1995. Export-led growth and the four little dragons, The Journal of International Trade and Economic Development 4(2): 203-215. doi:10.1080/09638199500000017

Jung, W. S.; Marshall, P. J. 1985. Exports, growth and causality in developing countries, Journal of Development Economics 18(1): 1-12. doi:10.1016/0304-3878(85)90002-1

Katircioglu, S. 2009. Trade, tourism and growth: The case of Cyprus, Applied Economics 41(21): 2741-2750. doi:10.1080/00036840701335512

Koccat, H. 2008. Exchange rates, exports and economic growth in Turkey: Evidence from Johansen cointegration tests, International Journal of Economic Perspectives 2(1): 5-11.

Krugman, P. 1979. A model of balance of payments crises, Journal of Money, Credit and Banking 11(3): 311-325. doi:10.2307/1991793

Kuznets, S. 1966. Economic growth of small nations, the modern economic growth. Yale University Press: London.

Lancaster, K. 1980. Intra-industry trade under perfect monopolistic competition, Journal of International Economics 10(2): 151-175. doi:10.1016/0022-1996(80)90052-5

Marin, D. 1992. Is export-led hypothesis valid for industrialized countries? Review of Economics and Statistics 74: 678-688. doi:10.2307/2109382

Mehmet, O.; Tahiroglu, M. 2002. Growth and equity in microstates: Does size matter in development? International Journal of Social Economics 29(1-2): 152-162. doi:10.1108/03068290210413047

Narayan, P. K. 2005. The saving and investment nexus for China: evidence from cointegration tests, Applied Economics 37(17): 1979-1990. doi:10.1080/00036840500278103

Narayan, P. K.; Narayan, S. 2005. Estimating income and price elasticities of imports for Fiji in a contegration framework, Economic Modelling 22(3): 423-438.

doi:10.1016/j.econmod.2004.06.004

Narayan, P. K.; Smyth, R. 2004. The relationship between the real exchange rate and balance of payments: empirical evidence for China from co-integration and causality testing, Applied Economic Letters 11(5): 287-291. doi:10.1080/1350485042000221535

Omotor, D. G. 2008. The role of exports in the economic growth of Nigeria: The bounds test analysis, International Journal of Economic Perspectives 2 (4): 222-235.

Pesaran, M. H.; Shin, Y. 1999. An autoregressive distributed lag modelling approach to cointegration analysis, in S. Strøm. Econometrics and Economic Theory in the 20th Century: The Ragnar Frisch Centennial Symposium. Cambridge University Press: Cambridge, 371-413.

Pesaran, M. H.; Shin, Y.; Smith, R. J. 2001. Bounds testing approaches to the analysis of level relationships, Journal of Applied Econometrics 16(3): 289-326. doi:10.1002/jae.616

Phillips, P. C. B.; Perron, P. 1988. Testing for a unit root in time series regression, Biometrika 75(2): 335-346. doi:10.1093/biomet/75.2.335 
Proudman, J.; Redding, S.; Bianchi, M. 1998. Openness and growth, in Proceedings of the Bank of England Academic Conference on the Relationship between Openness and Growth in the United Kingdom, September 15 ${ }^{\text {th }}$, 1997. Bank of England: Martins Printing Group: U.K.

Rivera-Batiz, L.; Romer, P. M. 1991. Economic integration and endogenous growth, Quarterly Journal of Economics 106(2): 531-555. doi:10.2307/2937946

Shun, J.; Sun, F. 1998. Domestic saving and foreign investment in Australia: A Granger causality test, International Economic Journal 12: 79-87. doi:10.1080/10168739800080030

Sims, C. A. 1972. Money, income, and causality, American Economic Review 62(4): 540-552.

State Planning Organization (SPO). 2009. Economic and Social Indicators. North Cyprus: Follow Up And Coordination Department, Prime Ministry, Nicosia.

Stilianos, F.; Jyh-Lin, W. 1999. Are the U.S. current account deficits really sustainable? International Economic Journal 13(3): 51-58. doi:10.1080/10168739900080020

Tvaronavičius, V.; Tvaronavičienè, M. 2008. Role of fixed investments in economic growth of country: Lithuania in European Context, Journal of Business Economics and Management 9(1): 57-64. doi:10.3846/1611-1699.2008.9.57-64

Wilson, R. 1992. Cyprus and the international economy. St Martin's Press, London.

$\mathrm{Xu}, \mathrm{Z}$. 1998. Export and income growth in Japan and Taiwan, Review of International Economics 6(2): 220-233. doi:10.1111/1467-9396.00099

$\mathrm{Xu}, \mathrm{X}$. 1996. On the causality between export growth and GDP growth: An empirical re-investigation, Review of International Economics 4(2): 172-184.

doi:10.1111/j.1467-9396.1996.tb00094.x

Yanikkaya, H. 2003. Trade openness and economic growth: A cross country empirical investigation, Journal of Development Economics 72(1): 57-89. doi:10.1016/S0304-3878(03)00068-3

Yeşilada, B.; Bıçak, H. 1995. The European court of justice decision on trade with northern Cyprus: Implications for the Cyprus conflict, in Presented to the Conference of the 91th Annual Meeting and Exhibition of the American Political Science Association, Chicago, U.S.A.

\section{PREKYBA IR AUGIMAS NEPRIPAŽINTOJE MAŽOJE SALOS VALSTYBĖJE: TURKIJOS RESPUBLIKOS ŠIAURĖS KIPRO ATVEJO TYRIMAS}

\section{S. Katircioglu}

Santrauka

Straipsnyje, remiantis empiriniais duomenimis, tyrinėjama ilgalaikẻ pusiausvyra bei priežastinis ryšys tarp tarptautinès prekybos ir ekonominio augimo Šiaurès Kipre, kuris yra nepripažintas ir kenčia dèl šios politinès problemos daugiau negu 40 metų. Empirinio tyrimo rezultatai leidžia teigti, kad tarp tarptautinès prekybos rodiklių (prekių ir paslaugų eksporto bei importo) bei ekonominio augimo šioje mažoje saloje vyrauja ilgalaikè pusiausvyra. Tyrimas patvirtina hipotezę apie eksporto kaip ekonominio augimo veiksnio svarba, bet paneigia importo itaką nagrinèjamos mažos šalies plètrai. Autorius ragina skatinti ne tik paslaugų, bet ir produkcijos eksportą norint pasiekti spartesni ekonomikos augimo mastą Šiaurès Kipre.

Reikšminiai žodžiai: tarptautinė prekyba, ekonominis augimas, priežastingumas, Šiaurès Kipras. 
Salih Turan KATIRCIOGLU is an Associate Professor of Economics in the Department of Banking and Finance, Faculty of Business and Economics, Eastern Mediterranean University, Famagusta, North Cyprus, Via Mersin 10, Turkey. He graduated from the same institution and earned his $\mathrm{PhD}$ from Uludag University, Turkey. His research interests include applied time series econometrics, international trade, international finance, tourism economics, and economic growth issues. He serves as an editor in the English-language journal, International Journal of Economic Perspectives. He has previously published or almost to publish in many international peer-review journals such as The World Economy, Applied Economics, Tourism Management, Applied Economics Letters, International Journal of Manpower, International Journal of Bank Marketing, and International Journal of Social Economics. 